\title{
Role of nitric oxide synthase in release of endothelin from cultured human endometrial cells
}

\author{
Zhang Lin, Toshiro Kubota, Mikako Masuda and Takeshi Aso \\ Department of Obstetrics and Gynecology, Faculty of Medicine, Tokyo Medical and Dental University, 1-5-45, Yushima, Bunkyo-ku, Tokyo 113, Japan \\ (Correspondence should be addressed to T Kubota)
}

\begin{abstract}
The aim of this study was to investigate the influence of the nitric oxide/nitric oxide synthase (NO/NOS) system on the release of endothelin-1 (ET-1) in human endometrial cells. Human endometrial stromal cells in secretory phase were incubated for $72 \mathrm{~h}$ in serum-free RPMI 1640 medium in the absence or presence of different concentrations of interleukin- $1 \beta$ (IL-1 $\beta$ ) and $N^{\mathrm{G}}$-monomethyl-L-arginine (LNMMA), a specific competitive inhibitor of NOS. ET-1 released from the cultured cells into the medium was determined by specific RIA. In all the experiments at various times, IL- $1 \beta$ significantly increased the release of ET-1. LNMMA significantly attenuated the release of ET-1 when the cells were cultured with both IL-1 $\beta$ and LNMMA, but LNMMA alone had no effect on ET-1 release. These results suggest that the NO/NOS system in human endometrium is involved in the regulation of ET-1 release via IL-1 $\beta$ secretion. It can also be inferred that NO and ET-1 control the functions of endometrium in close association with IL-1 $\beta$.
\end{abstract}

European Journal of Endocrinology 138 467-471

\section{Introduction}

It has been demonstrated that vascular endothelial cells are able to synthesize nitric oxide (NO) from L-arginine by the catalytic action of NO synthase (NOS) (1). Recently, the existence of this biochemical pathway in many other kinds of cells has been thoroughly documented and its relevance in biology is becoming clear (2). In addition to its vasodilating activity, NO is reported to play a vital role in the female reproductive system. This novel multifunctional free radical has been found to be involved in modulation of ovarian (3) and uterine (4) function. In particular, the ovarian NO/NOS system seems to play an important role in the regulation of ovulation (3) and in the suppression of steroidogenesis in granulosa cells $(5,6)$. This inorganic free radical gas is synthesized by a family of at least three isoenzymes in mammalian cells: the calcium-dependent constitutive isoform present in the neurons of the central and peripheral nervous system (nNOS) (7), the constitutive endothelial isoform (eNOS) (8) and the calcium-independent inducible isoform (iNOS). iNOS is induced by bacterial lipopolysaccharide and certain cytokines in a number of cell types including macrophages (9), ovarian cells (10), hepatocytes (11) and vascular smooth muscle cells (12).

Endothelin (ET) was originally isolated from the supernatant of cultured porcine vascular endothelial cells (13), and is a potent and long-lasting vasoconstricting peptide made up of 21 amino acids.
The human ET family is composed of three isopeptides, ET-1, ET-2 and ET-3 (14). Specific receptors for ET and mRNA for prepro-ET-1, the precursor of ET-1, are widely distributed in a variety of human tissues (15, 16), suggesting that ET-1 has multiple physiological functions, not only in the cardiovascular system but also in non-vascular systems. Many reports have suggested that ET-1 has a functional role in the female reproductive system (17), particularly in the human endometrium (18). However, no studies of the relation between the NO/NOS system and ET-1 secretion in the endometrium have so far been reported as far as we know.

The role of interleukin- $1 \beta$ (IL-1 $\beta$ ) in human endometrium is a subject of intense interest at present. IL- $1 \beta$, which induces iNOS, is reported to control the functional differentiation of human endometrial stromal cells (19). The present study was undertaken to investigate the possible role of the NO/NOS system as a local regulator of the release of ET-1 from human endometrial stromal cells.

\section{Materials and methods}

\section{Chemicals}

Chemicals were obtained from the following sources. Roswell Park Memorial Institute (RPMI) 1640 medium, DNase, collagenase (125-200 IU/mg), fetal bovine serum (FBS), antibiotic antimycotic solution, and 
Dulbecco's phosphate-buffered saline (D-PBS) were purchased from Gibco (Grand Island, NY, USA). IL-1 $\beta$ was obtained from Otsuka Pharmaceutical Co. (Tokushima, Japan), and $N^{\mathrm{G}}$-monomethyl-L-arginine (LNMMA) from Calbiochem Co. (La Jolla, CA, USA). Tissue culture plastic multiwell plates came from Falcon (Rockford, IL, USA). All other reagents were supplied by Sigma Chemical Co. (St Louis, MO, USA).

\section{Tissue samples}

Human endometrial tissues in the secretory phase were obtained from 16 patients (age range 40-49 years; mean age $45.0 \pm 1.0$ years) undergoing hysterectomy because of benign uterus disease, including myoma uteri and exogenous endometriosis. With the informed consent of each woman, all of the sampling and use of these tissues for this study were approved by the ethical committee of the Tokyo Medical and Dental University Hospital, Japan. The estimated day of the cycle was normalized to an idealized 28-day interval using: (i) the women's menstrual history; (ii) histological examination of the endometrium; (iii) plasma concentration of progesterone. All patients had received no hormone treatment in the three months before surgery, and were otherwise healthy. With scissors and pincette, endometrial tissue was scraped from the uterus immediately after hysterectomy, thoroughly washed with physiological saline, then placed in RPMI 1640 medium without FBS, and taken quickly to the laboratory.

\section{Cell culture}

The specimens were cut into multiple blocks from which blood clots and capillaries were eliminated. By the use of methods described previously (20), these specimens were enzymatically dispersed with collagenase $(2 \mathrm{mg} / \mathrm{ml})$ and DNase $(50 \mu \mathrm{g} / \mathrm{ml})$. Endometrial stromal cells were filtered and separated from epithelial cells by using a steel mesh $(38 \mu \mathrm{m})$. The cells were suspended in RPMI 1640 medium containing 10\% FBS and antibiotics. The number of viable endometrial cells was counted by the dye exclusion method using $0.4 \%$ trypan blue. The viable cells were then inoculated into two 24-well culture plates at a density of $1 \times 10^{6} /$ well and preincubated for $72 \mathrm{~h}$ in a humidified $37^{\circ} \mathrm{C}$ atmosphere of $5 \%$ carbon dioxide $/ 95 \%$ air (21). On the day of the experiment, microscopic inspection revealed that almost all of the culture cells were stromal/fibroblast-like in appearance, without epithelial cell contamination. These results were immunocytochemically confirmed by staining with anti-vimentin and anti-cytokeratin. The medium was changed, and then 24 wells of the cells were divided into four groups. (1) In the first six wells, the cells were incubated in serum-free RPMI 1640 medium as control. (2) The second six wells of cells were incubated with a final concentration of $10 \mathrm{ng} / \mathrm{ml}$ IL- $1 \beta$ in the same medium. (3) The final concentration of IL- $1 \beta$ in the third six wells was $100 \mathrm{ng} / \mathrm{ml}$. (4) The last six wells of cells were cultured with $100 \mathrm{ng} / \mathrm{ml} \mathrm{IL-} \beta$ and $1.0 \mathrm{~mm}$ LNMMA, a competitive inhibitor of NOS. All the groups were incubated for $72 \mathrm{~h}$. The medium was changed every $24 \mathrm{~h}$, centrifuged and stored frozen until assayed. At the end of the culture period, the endometrial cells were washed twice with D-PBS, and then frozen at $-20{ }^{\circ} \mathrm{C}$ until protein assay.

Another cell culture was produced to evaluate the effect of LNMMA on ET-1 release without IL- $1 \beta$ after $72 \mathrm{~h}$ of preincubation. The endometrial stromal cells were incubated with LNMMA (0.01-1.0 mM) alone for $24 \mathrm{~h}$ under the same conditions. At the end of the culture period, the medium was removed and stored frozen until assayed for hormone.

\section{RIA of ET-1}

ET-1 in the culture medium was measured by RIA using ${ }^{125}$ I-ET-1 as a tracer and synthetic ET-1 as a standard, as reported previously $(17,22)$. ET-1 was obtained from Peptide Institute Inc. (Osaka, Japan) and ${ }^{125}$ I-ET-1 (specific activity $74 \mathrm{TBq} / \mathrm{mmol}$ ) from Amersham Japan (Tokyo, Japan). The antibody employed in the RIA (17) demonstrated $100 \%$ cross-reactivity with ET-1, ET-2 and ET-3, but less than 1\% with big-ET-1. The final dilution of the antibody was 1:12 000; the sensitivity was $1 \mathrm{~mol} /$ tube and the $50 \%$ intercept was $14 \mathrm{fmol} /$ tube. The coefficients of intra-assay and interassay variability were 3.2 and $8.6 \%$ respectively.

\section{Bio-Rad protein assay}

The protein content of the endometrial cells in each well was measured by the Bio-Rad protein assay (Bio-Rad Laboratories, Hercules, CA, USA), as reported previously (23). Human albumin (Sigma Chemical Co.) was used for preparation of a standard curve. Finally, the protein content was assayed using a spectrophotometer by the standard procedure.

\section{Statistics}

Data are expressed as the mean \pm s.D. for groups consisting of six wells. ANOVA was used to determine the statistical significance of the differences, with $P<0.05$ being considered as statistically significant. The experiment was repeated three times to ensure reproducibility of the results, and one representative result is presented in each figure.

\section{Results}

\section{Effect of IL-1 $\beta$ and LNMMA on ET-1 release}

During the first, second and third $24 \mathrm{~h}$ culture, IL-1 $\beta$ $(10-100 \mathrm{ng} / \mathrm{ml})$ significantly $(P<0.0001)$ increased the release of ET-1 from the cultured endometrial stromal cells: $100 \mathrm{ng} / \mathrm{ml}$ IL-1 $\beta$ enhanced ET-1 release 
Table 1 Total ET-1 release in culture medium of human endometrial stromal cells cultured for $72 \mathrm{~h}$. Values are mean \pm S.D.

\begin{tabular}{ccc}
\hline $\begin{array}{l}\text { IL-1 } \beta \\
(\mathrm{ng} / \mathrm{ml})\end{array}$ & $\begin{array}{c}\text { LNMMA } \\
(\mathrm{mM})\end{array}$ & $\begin{array}{c}\text { Total ET-1 } \\
(\mathrm{pg} / \mathrm{ml} \text { per 106 }\end{array}$ \\
\hline 0 & 0 & $215.5 \pm 13.1^{\mathrm{a}}$ \\
10 & 0 & $462.1 \pm 39.3^{\mathrm{b}}$ \\
100 & 0 & $498.4 \pm 20.4^{\mathrm{b}}$ \\
100 & 1.0 & $394.4 \pm 27.5^{\mathrm{c}}$ \\
\hline${ }^{\mathrm{a}} P<0.0001 \mathrm{vs}^{\mathrm{b}}{ }^{\mathrm{b}}{ }^{\mathrm{b}} P<0.005 \mathrm{vs}^{\mathrm{c}}$.
\end{tabular}

by $52.0 \pm 31.0 \%$ in the first (Fig. 1A), by $89.5 \pm 17.9 \%$ in the second (Fig. 1B), and by $286.1 \pm 28.8 \%$ in the third (Fig. 1C) $24 \mathrm{~h}$ culture. In contrast, the level of ET-1 significantly $(P<0.01)$ decreased when the cells were
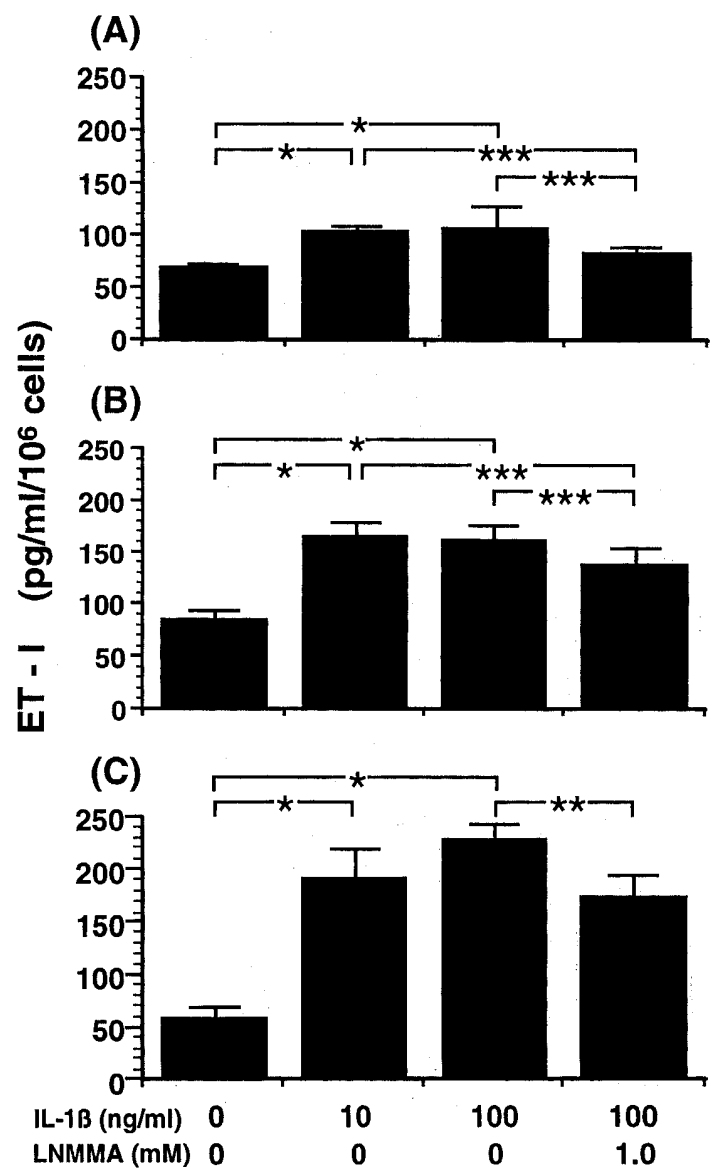

Figure 1 Effect of IL- $1 \beta$ and LNMMA on ET-1 release from cultured human endometrial stromal cells in the first (A), second (B) and third (C) $24 \mathrm{~h}$ culture. Cells were incubated with or without IL-1 $\beta$ in the absence or presence of LNMMA at $37^{\circ} \mathrm{C}$ in RPMI 1640 medium without fetal bovine serum. Each value represents the mean \pm S.D. for groups of six wells. IL- $1 \beta$ significantly stimulated ET- 1 release, and LNMMA significantly attenuated the release of ET- 1 from IL- $1 \beta$ stimulated endometrial stromal cells. ${ }^{\star} P<0.0001,{ }^{\star \star} P<0.005$, ${ }^{* * *} P<0.01$ incubated simultaneously with $100 \mathrm{ng} / \mathrm{ml} \mathrm{IL-} 1 \beta$ and $1.0 \mathrm{mM}$ LNMMA compared with that with $100 \mathrm{ng} / \mathrm{ml}$ IL-1 $\beta$ alone. Therefore LNMMA significantly $(P<0.01)$ attenuated the release of ET- 1 from IL-1 $\beta$-stimulated endometrial cells during the $72 \mathrm{~h}$ culture (Table 1): $1 \mathrm{mM}$ LNMMA decreased ET-1 release by $22.4 \pm 6.3 \%$ in the first (Fig. 1A), by $14.7 \pm 10.3 \%$ in the second (Fig. 1B), and by $24.6 \pm 10.3 \%$ in the third (Fig. 1C) $24 \mathrm{~h}$ culture from the $\mathrm{IL}-1 \beta(100 \mathrm{ng} / \mathrm{ml})$-stimulated cells.

The effect of LNMMA alone on ET-1 release is shown in Table 2. Without the co-effect of IL-1 $\beta$, LNMMA had no significant effect.

\section{Effect of IL-1 $\beta$ and LNMMA on cell proliferation}

Bio-Rad protein assay of the endometrial stromal cells (Table 3) showed no significant change in protein concentration among the four groups after $72 \mathrm{~h}$ of culture. Therefore neither IL- $1 \beta$ nor LNMMA had any significant effect on proliferation of human endometrial stromal cells.

\section{Discussion}

The discovery of the NO/NOS system has opened up a new field of research on the female reproductive system, particularly the endometrium. NOS activity has been reported to be present in the endometrium of nonpregnant sheep (24). Recently, Telfer et al. (25) demonstrated the presence of eNOS mRNA and protein in human endometrium and myometrium using in situ hybridization and immunocytochemistry. Recent work has shown that human endometrial glandular cells express eNOS mRNA throughout the menstrual cycle, while the expression of iNOS mRNA is confined to epithelial glands isolated from menstrual endometrium (26). iNOS-like immunoreactivity was also demonstrated in glandular epithelial cells, but eNOS and iNOS could not be detected in human endometrial stromal cells by immunocytochemical methods (27). On the other hand, although several studies have focused on the effect of ET on NO production in glomerular mesangial cells $(28,29)$ and vascular smooth muscle

Table 2 Effect of LNMMA alone on ET-1 release from cultured endometrial stromal cells. Values are mean + S.

\begin{tabular}{lc}
\hline $\begin{array}{l}\text { LNMMA } \\
(\mathrm{mM})\end{array}$ & $\begin{array}{c}\text { Total ET-1 } \\
\left(\mathrm{pg} / \mathrm{ml} \text { per } 10^{6} \text { cells }\right)\end{array}$ \\
\hline 0 & $26.5 \pm 3.0$ \\
0.01 & $24.8 \pm 3.3$ \\
0.01 & $23.8 \pm 3.3$ \\
1.0 & $24.2 \pm 4.3$ \\
\hline
\end{tabular}


Table 3 Effect of IL- $1 \beta$ and LNMMA on protein concentration in $72 \mathrm{~h}$ cultures. Values are mean \pm S.D.

\begin{tabular}{ccc}
\hline $\begin{array}{l}\mathrm{IL}-1 \beta \\
(\mathrm{ng} / \mathrm{ml})\end{array}$ & $\begin{array}{c}\text { LNMMA } \\
(\mathrm{mM})\end{array}$ & $\begin{array}{c}\text { Protein } \\
\left(\mu \mathrm{g} / 10^{6} \text { cells }\right)\end{array}$ \\
\hline 0 & 0 & $230.1 \pm 12.1$ \\
10 & 0 & $225.3 \pm 7.5$ \\
100 & 0 & $225.1 \pm 11.1$ \\
100 & 1.0 & $225.3 \pm 11.2$ \\
\hline
\end{tabular}

cells (30), the effect of NO on the release of ET from human endometrium remains to be investigated. In this study, we try to demonstrate the interaction between the NO/NOS system and the control of ET release, and investigate the role of $\mathrm{NO}$ as a potential mediator of ET release from human endometrial stromal cells in vitro.

The data reveal that IL- $1 \beta$ significantly stimulated ET-1 release from cultured human endometrial stromal cells in $72 \mathrm{~h}$ cultures, which is consistent with the report by Economos et al. (18). Furthermore, LNMMA, a competitive inhibitor of NOS, significantly attenuated the release of ET- 1 from IL- $1 \beta$-stimulated endometrial cells, and a direct effect of LNMMA could be excluded because LNMMA alone did not affect the ET release. We previously reported that LNMMA significantly decreased nitrite production in a $24 \mathrm{~h}$ cell culture system (6). Therefore these results imply that NOS probably induced by IL- $1 \beta$ has some positive effects on the release of ET-1 from endometrial stromal cells, and that the NO/NOS system is involved in the control of endometrial function in association with the physiological activity of ET. Another possibility is that IL-1 $\beta$ suppresses apoptosis in several cells by increasing NO generation (31)

It has been reported that human endometrial cells synthesize and release ET-1 throughout the normal menstrual cycle, and that mRNAs for prepro-ET-1, ETA and ETB receptor have been identified in the human endometrium $(18,21)$. These findings suggest that ET may have a potential autocrine and/or paracrine function in human endometrial cells. In the present study, we demonstrate that the NO/NOS system has a role in the control of ET secretion via the action of cytokines. As macrophages are present in the endometrium and in blood vessels, IL-1 $\beta$ produced by macrophages may activate iNOS in human endometrium. Although the physiological function of ET in human endometrial cells has not been clarified, Economos et al. (18) have recently reported the biological roles of ET in human endometrium. ET may have a physiological role in the autocrine/paracrine regulation of uterine blood flow by causing contraction of endometrial blood vessels and uterine muscle during menstruation, re-epithelization via cell proliferation in the proliferative phase, and production of glandular epithelium in human endometrium involved in blastocyst apposition/implantation. The finding that NOS activity has a close relation to the control of ET release in human endometrium suggests that the $\mathrm{NO} /$ NOS system may play an important role in the local regulation of uterine function.

In conclusion, we have shown that an intimate relation exists between the release of ET and NOS activity, and that IL- $1 \beta$ may influence the release of ET from human endometrial cells through the involvement of the NO/NOS system in addition to having a direct effect. Therefore it is likely that NO production by iNOS is important in endometrial function, and is closely related to IL-1 $\beta$ activity in human endometrium. We suggest that the cooperative biological effects between $\mathrm{NO}$ and ET may contribute to the regulation of human uterine blood flow, uterine contractility and probably several other physiological actions.

\section{Acknowledgements}

This work was supported by a science research grant (06671633) to T K from the Ministry of Education, Science and Culture of Japan. We gratefully thank Miss Kurosawa for excellent technical help in the course of the study.

\section{References}

1 Palmer RMJ, Ferrige AG \& Moncada S. Nitric oxide release accounts for the biological activity of endothelium-derived relaxing factor. Nature 1987327 524-526.

2 Moncada S, Palmer RMJ \& Higgs EA. Nitric oxide: physiology, pathophysiology, and pharmacology. Pharmacological Reviews $199143109-142$.

3 Shukovski L \& Tsafriri A. The involvement of nitric oxide in the ovulatory in the rat. Endocrinology 1994135 2287-2290.

4 Yallampalli C, Izumi H, Byam-Smith M \& Garfield RE. An L-arginine-nitric oxide-cyclic guanosine monophosphate system exists in the uterus and inhibits contractility during pregnancy. American Journal of Obstetrics and Gynecology 1994170 175-185.

5 Bonello N, McKie K, Jasper M, Andrew L, Ross N, Braybon E et al. Inhibition of nitric oxide: effect of interleukin-1-enhanced ovulation rate, steroid hormones, and ovarian leukocyte distribution at ovulation in the rat. Biology of Reproduction 199654 436-445.

6 Masuda M, Kubota T, Kamada S \& Aso T. Nitric oxide inhibits steroidogenesis in cultured porcine granulosa cells. Molecular Human Reproduction 19973 285-292.

7 Bredt DS, Hwang PM, Glatt CE, Lowenstein C, Reed RR \& Snyder SH. Cloned and expressed nitric oxide synthase structurally resembles cytochrome P450 reductase. Nature $1991351714-$ 719 .

8 Sessa WC, Harrison JK, Barber CM, Zeng D, Durieux ME, D’Angelo DD et al. Molecular cloning and expression of cDNA encoding endothelial cell nitric oxide synthase. Journal of Biological Chemistry 1992267 15274-15276.

9 Xie Q, Cho HJ, Calaycay J, Mumford RA, Swiderek KM, Lee TD et al. Cloning and characterization of inducible nitric oxide synthase from mouse macrophages. Science 1992256 225-228.

10 Ellman C, Corbett JA, Misko TP, McDaniel M \& Beckerman KP. Nitric oxide mediates interleukin-1-induced cellular cytotoxicity in the rat ovary: a potential role for nitric oxide in the ovulatory process. Journal of Clinical Investigation 199392 3053-3056.

11 Evans T, Carpenter A \& Cohen J. Purification of a distinctive form of oviduct tissue-conditioned medium for the culture of early bovine embryos. Journal of Reproduction and Fertility 199292 59-64. 
12 Nunokawa Y, Ishida N \& Tanaka S. Cloning of inducible nitric oxide synthase in rat vascular smooth muscle. Biochemical and Biophysical Research Communications 1993191 89-94.

13 Yanagisawa M, Kurihara H, Kimura S, Tomobe Y, Kobayashi M, Mitsui Yet al. A novel potent vasoconstrictor peptide produced by vascular endothelial cells. Nature $1988332411-415$.

14 Inoue A, Yanagisawa M, Kimura S, Kasuya Y, Miyauchi T, Goto K et al. The human endothelin family: three structurally and pharmacologically distinct isopeptides predicate by three separate genes. Proceedings of the National Academy of Sciences of the USA $1989862863-2867$.

15 Fischli W, Clozel M \& Guilly C. Specific receptors for endothelin on membrane from human placenta. Characterization and use in a binding assay. Life Sciences 198944 1429-1436.

16 Koseki C, Imai M, Hirata Y, Yanagisawa M \& Masaki T. Autoradiographic distribution in rat tissues of binding sites for endothelin: a neuropeptide? American Journal of Physiology 1989 $256858-866$

17 Kubota T, Kamada S, Hirata Y, Eguchi S, Imai T, Marumo F et al. Synthesis and release of endothelin-1 by human decidual cells. Journal of Clinical Endocrinology and Metabolism 199275 12301234.

18 Economos K, MacDonald PC \& Casey ML. Endothelin-1 gene expression and protein biosynthesis in human endometrium: potential modulator of endometrial blood flow. Journal of Clinical Endocrinology and Metabolism 199274 14-19.

19 Kariya M, Kanzaki H, Takakura K, Imai K, Okamoto N, Emi N et al. Interleukin-1 inhibits in vitro decidualization of human endometrial stromal cells. Journal of Clinical Endocrinology and Metabolism 199173 1170-1174.

20 Satyaswaroop PC, Bressler RS, De La Pena MM \& Gurpide E. Isolation and culture of human endometrial glands. Journal of Clinical Endocrinology and Metabolism 197948 639-641.

21 Kubota T, Taguchi M, Kamada S, Imai T, Hirata Y, Marumo F et al. Endothelin synthesis and receptors in human endometrium throughout the normal menstrual cycle. Molecular Human Reproduction $199512204-2208$.

22 Kamada S, Kubota T, Hirata Y, Taguchi M, Eguchi S, Marumo F et al. Endothelin-1 is an autocrine/paracrine regulator of porcine granulosa cells. Journal of Endocrinological Investigation 199316 425-431.

23 Bradford MM. A rapid and sensitive method for the quantitation of microgram quantities of protein utilizing the principle of protein-dye binding. Analytical Biochemistry 197672 248-254.

24 Figueroa JP \& Massmann GA. Estrogen increases nitric oxide synthase activity in the uterus of nonpregnant sheep. American Journal of Obstetrics and Gynecology 1994173 1539-1545.

25 Telfer JF, Lyall F, Norman JE \& Cameron IT. Identification of nitric oxide synthase in human uterus. Human Reproduction 199510 19-23.

26 Tseng L, Zhang JZ, Peresleni TY \& Goligorsky MS. Cyclic expression of endothelial nitric oxide synthase mRNA in the epithelial glands of human endometrium. Journal of the Society for Gynecological Investigation 19963 33-38.

27 Telfer JF, Irvine GA, Kohnen G, Campbell S \& Cameron IT. Expression of endothelial and inducible nitric oxide synthase in non-pregnant and decidualized human endometrium. Molecular Human Reproduction 19973 69-75.

28 Owada A, Tomita K, Terada Y, Sakamoto H, Nonoguchi H \& Marumo F. Endothelin (ET)-3 stimulates cyclic guanosine $3^{\prime}, 5^{\prime}$ monophosphate production via $\mathrm{ET}_{\mathrm{B}}$ receptor by producing nitric oxide in isolated rat glomerulus, and in cultured rat messangial cells. Journal of Clinical Investigation 199493 556-563.

29 Beck KF, Mohaupt MG, Sterzel RB, Peters S \& Fees H. Endothelin-1 inhibits cytokine-stimulated transcription of inducible nitric oxide synthase in glomerular mesangial cells. Kidney International 1995 48 1893-1899.

30 Ikeda U, Yamamoto K, Maeda Y, Shimpo M, Kanbe T \& Shimada K. Endothelin-1 inhibits nitric oxide synthesis in vascular smooth muscle cells. Hypertension 199729 65-69.

31 Chun SY, Eisenhauer KM, Kubo M \& Hsueh AJW. Interleukin-1 $\beta$ suppresses apoptosis in rat ovarian follicles by increasing nitric oxide production. Endocrinology 1995136 3120-3127.

Received 11 August 1997

Accepted 22 December 1997 